\title{
Phenotypic and Biochemical Characterization of a New Genotype of Satureja montana (L.)
}

\author{
Costel VÎNĂTORU*, Elena BARCANU, Ovidia Loredana DOBRE (AGAPIE), Ion GHERASE, Bianca TĂNASE \\ and Geanina NEGOȘANU
}

Vegetable Research-Development Station Buzau, 23 Mestecanului St, Buzau, Romania

* corresponding author: costel_vinatoru@yahoo.com

BulletinUASVM Horticulture 77(2) / 2020

Print ISSN 1843-5254, Electronic ISSN 1843-5394

DOI:10.15835/buasvmcn-hort: 2020.0041

\begin{abstract}
Satureja Montana L. is an underrated, but very valuable species with multiple uses appreciated especially for its anti-inflammatory, antibacterial, antifungal and antioxidant properties. At VRDS Buzau was obtained a new genotype of winter savory with high content in volatile oils, minerals and with a yield potential of over $4.802 \mathrm{~kg} /$ plant after five years of cultivation. The content in volatile oils was determined using gas chromatography and the main component of the volatile oils were: thymol (83.04\%), carvacrol (4.46\%), o-cymene (4.21\%) and other 13 components, in smaller percentages. The plant is perennial and can be grown for over 20 years.
\end{abstract}

Keywords: endemic, gas-chromatography, Lamiaceae, mineral content, volatile oils

\section{Introduction}

During the past years, numerous studies have been published on antioxidant and antimicrobial activity of bioactive plant extracts, strongly inspired by an increasing consumer interest in "natural" food aditives (antioxidants, preservatives, colours and flavours), as an alternative to the use of synthetic products (Serrano et al., 2011). It is known that the consumption of processed food containing bioactive volatile plant extracts (essential oils), commonly found in different part of the plant is expected to prevent the risk of many diseases, such as cancers, and the ageing process associated with the presence of free radicals (Gardeli et al., 2008). The principal molecules found in essential oils with strong antibacterial activity are phenol (carvacrol, thymol and eugenol), alcohols, aldehydes, kerones, ethers and phtdalids (Baudoux, 1991).

The Lamiaceae family is known as particulary important to humans for herb plants useful for flavour, fragrance or medicinal properties. The
Lamiaceae family has 263 genera and more than 7000 species. Among those genera, Satureja comprises over 200 different herbs or shrubs. All over the world, flowers, leaves, stem and seeds of most of the Satureja species are traditionally used for various diseases and complications such as gastrointestinal cramps, nausea, diarrhea, muscle pains, and infectious diseases (Gulluce et al., 2003). Because of the aromatic characteristics, leaves and aerial parts of this genus possess distinctive but pleasant tastes (Eminagaoglu et al., 2007).

This work is focused on Satureja montana L. a perennial, semi-bushy medicinal and aromatic plant. Winter savory is an endemic species in temperate region of Europe, the Mediterranean and Africa (Cetkovic et al., 2007), it prefers calcareous, alkaline soils and mountainous area.

Satureja montana is appreciated for its culinary uses, but especially for its anti-inflammatory, antibacterial, antifungal and antioxidant properties (López-Cobo et al., 2015). Among Satureja species, it seems that only $S$. montana has been evaluated 
for antiviral activities (human immunodeficiency virus-1 induced cytopathogenicity in MT-4 cells). The aqueous extract of this plant exerted strong antihuman immunodeficiency virus-1 activity (effective dose Z $16 \mathrm{~m} / \mathrm{mL}$ ) against the virus and also respective reverse transcriptase (Yamasaki et al., 1998).

In Romania, winter savory can be found in the mountain area as a native species. In crop culture, Satureja montana has met favourable growing conditions at VRDS Buzau were it is studied for almost 20 years. The aims of this study were phenotypic characterizations and determination of mineral and volatile oils content of a new genotype of Satureja montana grown at VRDS Buzau.

\section{Materials and methods}

The Breeding and Biodiversity Laboratory from VRDS Buzau has a valuable germplasm collection for Satureja sp. containing a large number of genotypes, of which eight are genetically stabilized. Of these, G6 was noted by distinct genotypic and phenotypic characteristics and was subjected to intensive breeding work. One of the main objectives of the study was to assess the evolution of the main characters of plant in the first years of cultivation and also the evaluation of the mineral and volatile oil content. The volatile oil content was determined using gas chromatography.

\section{Results and discussions}

Throughout years of study it was registered the evolution of the main characters (Tab. 1) and a continuous growth was observed until the fifth year of cultivation. After this period, the growth of the plant stagnated and the yield began to be relatively constant, being influenced only by environmental conditions.

The plant has a long flowering period, from the beginning of June until the end of September, being very appreciated and visited by bees. Winter savory can be multiplied by dividing and propagating the shrub, by cuttings or by seeds. The last option is less used because the seeds have a low germination rate. In growing culture, the plant began to have viable seeds only in the third year. For culinary uses and medicinal properties are used young shoots, which can be harvested at any time of the year, as a rule in general, can be made

Table 1. The evolution of the main characters of plants in the first years

\begin{tabular}{cccccc}
\hline Studied character & $1^{\text {st }}$ year & $2^{\text {nd }}$ year & $3^{\text {rd }}$ year & $4^{\text {th }}$ year & $5^{\text {th }}$ year \\
\hline Bush diameter $(\mathrm{cm})$ & 36 & 62 & 85 & 124 & 131 \\
\hline Plant height $(\mathrm{cm})$ & 21 & 33 & 35 & 54 & 62 \\
\hline Shoot length $(\mathrm{cm})$ & 4.2 & 5.4 & 8.3 & 14.5 & 28 \\
\hline Number of shoots/plant & 96 & 286 & 412 & 567 & 611 \\
\hline Shoot mass $(\mathrm{g})$ & 1.16 & 1.42 & 1.83 & 2.23 & 2.62 \\
\hline Leaf length $(\mathrm{cm})$ & 1.1 & 1.5 & 1.8 & 2.2 & 2.5 \\
\hline Leaf width $(\mathrm{cm})$ & 0.3 & 0.3 & 0.3 & 0.4 & 0.5 \\
\hline Yield/plant $(\mathrm{kg})$ & 0.334 & 1.218 & 2.261 & 3.793 & 4.802 \\
\hline
\end{tabular}

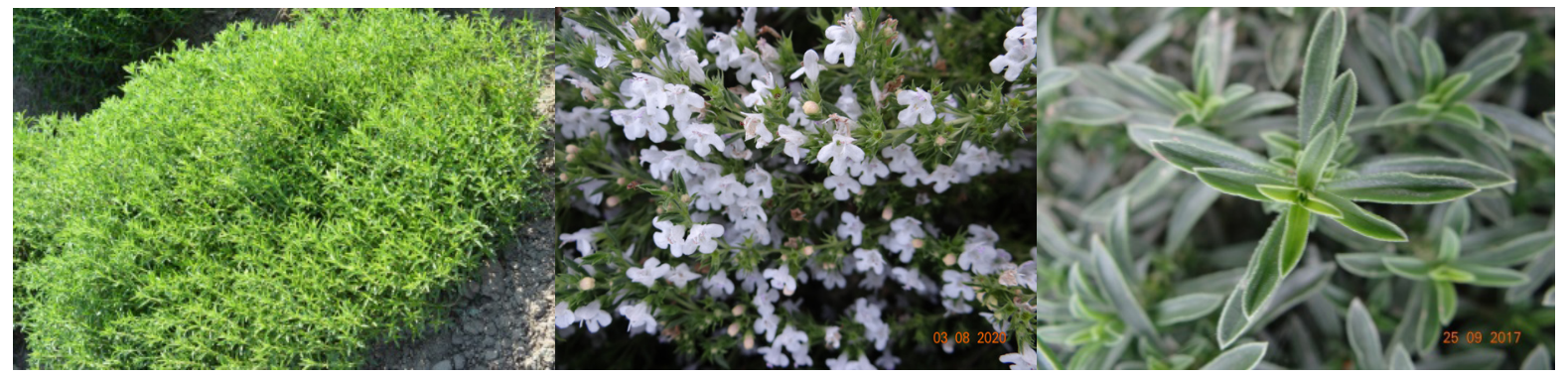

Figure 1. Crop detail, flowers and young shoots of Satureja montana 


\section{Volatile oil content $\%$}

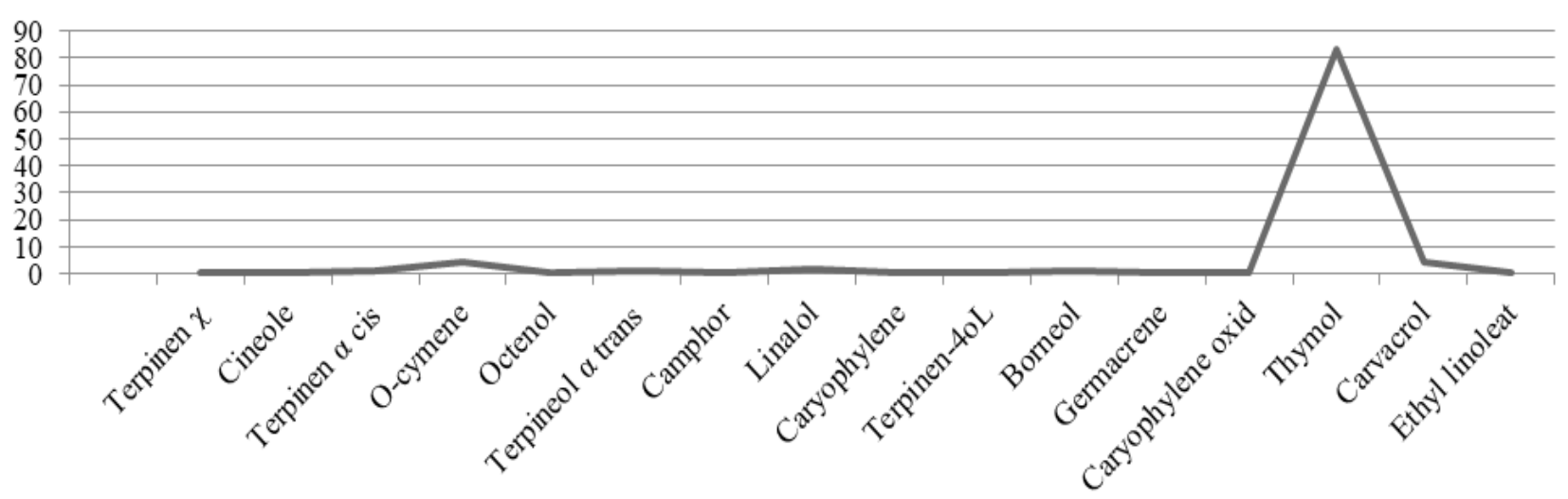

Figure 2. Volatile oil content of Satureja montana

3-4 time massive harvests/year. Plant details are presented in Figure 1.

After the $5^{\text {th }}$ year of cultivation, the yield per plant is relatively constant, reaching an average value of $4.802 \mathrm{~kg}$. The culture is economically profitable due to its multiple uses and can be exploited for a long period of time, over 20 years.

The mineral content of the young shoots was determined before flowering in May and the following results were obtained: $340 \mathrm{mg} / 100 \mathrm{~g} \mathrm{Ca}$, $140 \mathrm{mg} / 100 \mathrm{~g} \mathrm{Mg}, 1700 \mathrm{mg} / 100 \mathrm{~g} \mathrm{~K}, 115 \mathrm{mg} / 100$ $\mathrm{g} \mathrm{Na}, 4 \mathrm{mg} / 100 \mathrm{~g} \mathrm{Mn}, 14 \mathrm{mg} / 100 \mathrm{~g} \mathrm{Cu}, 123$ $\mathrm{mg} / 100 \mathrm{~g} \mathrm{Fe}$ and $4 \mathrm{mg} / 100 \mathrm{~g} \mathrm{Zn}$. In our research there were not detected any heavy metals such as Plumbum and Cadmium.

The content in volatile oils was determined in October using gas chromatograph and the main components of the volatile oils were: thymol (83.04\%), carvacrol (4.46\%), o-cymene $(4.21 \%)$, $\chi$-terpinen $(0.18 \%)$, cineole $(0.45 \%), \alpha$-cis-terpinen $(0.87 \%)$, octenol $(0.35 \%), \alpha$ - trans-terpineol $(0.85 \%)$, camphor $(0.60 \%)$, linalol $(1.96 \%)$, caryophylene $(0.48 \%)$, terpinen- 4 ol $(0.63 \%)$, borneol $(1.29 \%)$, germacrene $(0.24 \%)$, caryophylene oxid $(0.23 \%)$ and ethyl linoleat $(0.18)$, also represented in Figure 2. Similar results were obtained by Mastelić and Jerković (2003).

\section{Conclusions}

Winter savory is a valuable plant due to its high content of volatile oils, minerals and to antiviral properties. The plant can be cultivated throughout Romania as a perennial plant, with a vegetation period of over 20 years, with a high yield potential, can be harvest 3-4 times a year. It blooms for a long time, starting with June until the end of September, being also a valuable honey plant.

Acknowledgments. The work was supported by a grant of the Romanian Ministry of Research and Innovation, CCCDI - UEFISCDI, project number PN-III-P1-1.2-PCCDI-2017-0850/ contract 14 PCCDI /2018, within PNCDI III.

\section{References}

1. Baudoux D (1991). Antiviral and Antibacterial Properties of Essential Oils. [Online]. http://www.aromabar.com/ articles/ baud55.htm.

2. Ćetković GS, Ĉanadanović-Brunet JM, Djilas SM, Tumbas VT, Markov SL, Cvetković DD (2007). Antioxidant potential, lipid peroxidation inhibition and antimicrobial activities of Satureja montana L. subsp. kitaibelii extracts. Int. J. Mol. Sci. 8: 1013-1027.

3. Eminagaoglu O, Tepe B, Yumrutas O, Akpulat HA, Daferera D, Polissiou M, Sokmen A, (2007). The in vitro antioxidative properties of the essential oils and methanol extracts of Satureja spicigera (K. Koch.) Boiss. and Satureja cuneifolia ten. Food Chem. 100: 339-343.

4. Gardeli C, Papageorgiou V, Mallouchos A, Kibouris T, Komaitis M, (2008). Essencial oil composition of Pistacia lentiscus L. and Myrtus communis L.: Evaluation of antioxidant capacity of methanolic extracts. Food Chem. 107: 1120-1130.

5. Gulluce M, Sokmen M, Daferera D, Agar G, Ozkan H, Kartal N, Polissiou M, Sokmen A, Șahin F (2003). In vitro antibacterial, antifungal, and antioxidant activities of the essential oil and methanol extracts of herbal parts and callus cultures of Satureja hortensis L. J Agric Food Chem. 51: 3958-3965. 
6. López-Cobo A, Gómez-Caravaca AM, Švarc-Gajić J Segura-Carretero A, Fernández-Gutiérrez A (2015). Determination of phenolic compounds and antioxidant activity of a Mediterranean plant: The case of Satureja montana subsp. kitaibelii. J. Funct. Foods. 18: 1167-1178.

7. Mastelić J, Jerković I (2003). Gas chromatography-mass spectrometry analysis of free and glycoconjugated aroma compounds of seasonally collected Satureja montana L. Food chemistry. 80(1): 135-140
8. Serrano C, Matos O, Teixeira B, Ramos C, Neng N, Nogueira J, Marques A (2011). Antioxidant and antimicrobial activity of Satureja montana L. extracts. Journal of the Science of Food and Agriculture. 91(9): 1554-1560.

9. Yamasaki $\mathrm{K}$, Nakano M, Kawahata T, Mori H, Otake T, Ueba N, Oishi I, Inami R, Yamane M, Nakamura M, Murata H, Nakanishi T (1998). Anti-HIV-1 activity of herbs in Labiatae. Biol Pharm Bull. 21: 829-833. 